\title{
Bones of Contention: The Online Trade in Archaeological, Ethnographic, and Anatomical Human Remains on Social Media Platforms
}

\author{
Damien Huffer, Duncan Chappell, Nathan Charlton and Brian Spatola
}

\section{Introduction}

Academic attention is beginning to focus on documenting the existence and scale of a poorly regulated international marketplace for human remains which are being traded as objects of curiosity. Recent research (Carter et al. and see below) makes it increasingly clear that the continuation of this market in its current state poses a substantial risk to key areas of scientific inquiry and cultural preservation. Valuable skeletal specimens that were once preserved in museums or used in medical education or scientific research are finding their way into commercial and "underground" markets accessible through the internet; markets that readily make use of social media and e-commerce platforms such as Instagram, Facebook, the Dutch e-commerce platform Marktplaats, and others. Institutional neglect of specimens has contributed to a growth of the market for human remains by allowing deaccession of specimens to unqualified individuals instead of transferring them to other institutions for preservation.

The contemporary trade in human remains as currently understood from exploratory research (e.g. Huxley and Finnegan 2004; Kubiczek and Mellon 2004; Huffer and Chappell 2014) also represents an as-yet unassessed risk to what archaeology can understand about life in past times using osteological and mortuary data (e.g. Kinkopf and Beck 2016; O'Reilly 2007). The majority of research attempting to quantify burial looting using occurs via survey or the use of satellite imagery to access recent damage (e.g. Contreras 2010; Contreras and Brodie, 2013; Lasaponara et al. 2014). However, several contemporary examples from "hot-spots" such as Egypt (Popular Archaeology 2012) clearly demonstrate the continuing threat to cemetery integrity that indiscriminate looting still poses. Most cemeteries are looted to obtain grave goods (jewellery, ceramics, etc.), though discarded and fragmentary human remains can themselves be trafficked (e.g. Choi 2011). Recent examples have garnered media attention due to the rather shocking nature of the specimen being offered and the means of attempted sale (e.g. Killgrove 2016a). Only occasionally have the e-commerce platforms displaying these specimens taken action in response to exposure and public outcry (Halling and Seidemann 2016).

While a market for human remains has long existed (e.g. Spennemann 2006; Roque 2010) the new ability to conduct this activity via social media and online forums has facilitated these remains now being treated as consumer products for a collector's market, rather than objects of archaeological, ethnographic or anatomical value. To combat this practice some jurisdictions have introduced restrictions on the ownership and sale of human remains, including in some cases total bans (see in general Marquez-Grant and Fibiger 2011; Seidemann et al. 2009; Seidemann 2004). Internationally these restrictions represent a complex and often confusing area of the law which will be discussed in greater depth below.

However, it should be emphasised here that legal prohibitions on the professional acquisition or use of human remains can adversely affect their transfer from archaeological or medical contexts to museums because it precludes the passage of ownership through standard 
museum practices and procedures (i.e. deeds of gift) and instead requires the drafting of new legally-binding contracts to ensure compliance with relevant legislation, as was the recent US based in-person experience of co-author Spatola.

Even so, there are still relatively few domestic restrictions in the US at large (Federal or State level) on the private sale or ownership of human remains by private collectors. This situation, when coupled with the ease of US interstate, and even international shipping, strengthens the conditions that favour the circulation of human remains among private collectors based on their monetary value as objects of curiosity. This circulation may well extend to private as well as public collectors located outside the boundaries of the US, depending on the nature of the prevailing law in foreign jurisdictions.

This chapter focuses principally on the online private commercial market in human remains. It updates the general findings of earlier research conducted by two of the authors, Damien Huffer (DH) and Duncan Chappell (DC) (see Huffer and Chappell 2014), and expands this study to the largely unexplored social media territory of Instagram, presenting the first summary data derived from manual searches (as opposed to automated data mining) of this platform. Initially, we will situate the human remains trade within the larger antiquities trade itself. We will next demonstrate the existence of a separate community of collectors on Instagram (many of whom also make use of other social media platforms such as Facebook, Etsy, and (until recently) eBay). We will then review how Instagram operated at the time that the research was undertaken, what its then sales policy allegedly prohibited, and the size and scope of the trade as suggested by our initial research. We conclude by discussing future research directions.

\section{Background}

In 2014, DH and DC conducted a new exploratory study of what was then known about the global online trade in human remains and, in particular, specimens from archaeological or ethnographic contexts (Huffer and Chappell 2014). This 2014 study represented the first research on the global online trade in human remains since an article and associated commentary published in 2004 (Huxley and Finnegan 2004; Kubiczek and Mellon 2004) examined whether or not eBay, due to the lack of a physical anthropologist on their staff, was inadvertently selling human remains of medico-legal forensic import. The need was felt by $\mathrm{DH}$ and DC to pursue investigation of the online trade in human remains into the realm of archaeological and ethnographic specimens. In other words, the research presented below continues to explore the contradiction between the dead being viewed as cultural property in the eyes of the law, cultural heritage in the eyes of archaeologists and Indigenous people, and commoditized into 'objets d'art' in the eyes of the market.

While Huffer and Chappell (2014) suggested that the attempted open sale of human remains derived from freshly looted archaeological sites is a very rare occurrence, it remains impossible to know the true extent of the trade solely from a few online gallery webpages. The evidence at this stage suggests that the most prominent demand countries are located in North America and Europe, while the specimens and artefacts themselves can be sourced from a wide range of countries in African, Latin America, Southeast Asia and Oceania. This includes alleged recent historic or Medieval specimens with provenience states as being from "old collections" assembled by citizens of market countries themselves, such as Germany or Italy. 
Auction houses, smaller online galleries (occasionally associated with off-line dealers operating store fronts) and individual dealers were all found to be participants in the online trade in human remains. Prospective buyers could be divided into three broad and potentially overlapping categories; namely collectors of ethnographic ("tribal") art/curios; collectors of medical specimens for either legitimate educational purposes or as "macabre" novelty items; and practitioners of specific religious sects or practices, such as the Chöd healing rituals in Vajrayana Buddhism or Palo Mayombe (Gill et al. 2009). Marketing rhetoric and the degree of transparency provided by dealers regarding ownership history of remains and the legality of their import or export varied greatly, with most dealers providing nothing more on their websites than the suggestion that buyers "check local laws".

As discussed below, the more recent expansion of our research suggests that little has changed in the overall online marketing of human remains since our 2014 study. The US and UK, as in 2014, remain the primary "market" countries, although several European countries also contribute to supply and demand, most notably Belgium and the Netherlands. The most significant recent occurrence affecting the "public" metrics of the market has been the banning of the sale of real human remains by eBay (Halling and Siedemann 2016). In response to Halling and Siedemann's (2016) research documenting approximately 475 examples of human remains bought and sold from 2012-2013 (arguably the peak of the market on eBay), as well as increasing exposure of the problem in the media, this ecommerce platform took action (Vergano 2016). The ban from eBay seemed to effect a substantial transformation of the trade on the surface. However, the effect appears to be the migration of large proportions of the active trade to new online forums like Instagram.

\section{Instagram and the Circulation of Goods}

Instagram is an online photo/video sharing and social media networking service, currently a wholly owned subsidiary of Facebook. Like other forms of social media, trends and topics can be shared between users through the use of hashtags (\#), enabling users to search for topics of interest. Instagram users can link their profiles to other social media platforms, including, but not limited to Tumblr, Facebook, Twitter, Flickr, and eBay, thereby reaching much wider audiences. As of January 2017, it had 150 million active account users per month. Under its Terms of Use (2018), users may utilise the platform to promote brands, companies, products, and to advertise to other users. Effective engagement of users to purchase wares is centred on the use of "quality" photographs, promotional sales and events, and where possible, collaboration with other parties on and off Instagram. Users are also capable of messaging account owners directly to arrange sales.

The Instagram "Help Centre" contains (2019) a "Privacy and Safety Centre", in which users can find a wide variety of information and advice. The "Instagram Team" begins its presentation of platform rules and regulations under the tab "Community Guidelines" thusly:

"We want Instagram to continue to be an authentic and safe place for inspiration and expression. Help us foster this community. Post only your own photos and videos and always follow the law. Respect everyone on Instagram, don't spam people or post nudity."

Instagram has numerous rules and regulations that all users are supposed to comply with. Examples of rules relevant to this research include, under "Basic Terms"; Section 7: "...You 
may not use the Service for any illegal or unauthorized purpose. You agree to comply with all laws, rules and regulations (for example, federal, state, local and provincial) applicable to your use of the Service..." Under "General Conditions"; Section 8 “...Your correspondence and business dealings with third parties through the service are solely between you and the third party..." Under 'Regulated Goods and Services,' it is stated: “...If your photos or videos are promoting the sale of regulated goods or services, including firearms, alcohol, tobacco, prescription drugs, and adult products, please ensure that you know and are following the law that applies to you."

Though the trade, advertisement and sale of questionable materials is clearly prohibited by the rules and regulations put forth, many instances have been made public of the involvement of Instagram users in a range of activities which breach these platform rules. As reported by Bright et al. (2011) in their research into online drug trafficking, "social network analysis" has also been increasingly used to broaden the understanding of law enforcement agencies with regards to the general misuse of social media platforms in criminal activities, and indeed, whether such analyses may be of use for the detection of online crime. Although the investigations undertaken by Bright et al. specifically targeted known drug trafficking syndicates, there is evidence of social media platforms being exploited for a wide variety of questionable trading including that of human remains.

Previous studies into the relationships between criminal activities and the misuse of social media, including Instagram, have shown that the sale of hard and soft drugs are particularly prevalent. An article published online by Smith IV (2014) cites an infographic prepared by the Coalition Against Drug Abuse, which details the prevalence and extent of drug commerce on Instagram. In this investigation, the sale of cannabis was most frequently encountered, followed by opiates (codeine), MDMA (3,4-methylenedioxymethylamphetamine) and prescription painkillers.

Other suspect activities visible on social media platforms have also been widely reported on. These range from the recent crackdown on private gun sales by Facebook and Instagram (Goel and Isaac 2016) to evidence of human trafficking (Lillie 2013; Mangione 2016) and animal trafficking specifically via Instagram (Haslett, 2015). Haslett (2015) provides repeated instances of users seemingly deliberately breaching the proffered guidelines..

Aside from the activities referred to above, potentially less-substantiated reports also exist of the exploitation of social media platforms like Instagram by drug cartels and terrorist organisations, such as Daesh (e.g. Joffe 2016; Ruiz 2016). With regard to the former, use of new social media appears to involve the ostentatious display of wealth by high-ranking cartel members and associates (Fetcher 2016; Thomas 2016), grandiose acts that have been of use for law enforcement agencies targeting cartel activity.

It is our opinion that thesehese examples suggest that social media platforms are now viewed as favourable places on which to conduct (or market the proceeds of) various categories of commerce of questionable legality, despite their stated policies to the contrary. As the remainder of this chapter now illustrates, this includes a trade in human remains.

\section{The Human Remains Trade on Social Media}

We suggest from our research that like the sale of drugs, guns and other commodities, the trafficking of human remains, although smaller in scope and more 'esoteric,' is at present 
well-established and poorly controlled. Of note are the various means of display of human remains with some users proudly boasting of their collections while others admire such collections from afar, and amateur collectors and professional storefronts participate in the active sale, auction and free trade of human remains.

Significant portions of what is traded are leftovers from $c .1940-1980$, when human remains could be sourced legally and were widely available for sale to educational institutions (i.e. anatomical preparations). Educational supply companies like Carolina Biological Supply, Clay-Adams and many others sourced skeletal material from India, prior to that country's ban on exporting human remains in 1985 (Banerjie 2014). Often, this material is labelled and articulated with hardware and has the appearance of a typical classroom teaching skeleton. The prominence of this type of material online and its generally legal status lends a superficial impression of legitimacy to the market at large.

Specialists who are trained in physical and forensic anthropology are able to identify potentially illicit material hiding in plain sight. For example, one of the authors (BFS) recognized three separate questionable sales of human skulls on eBay in 2012, which ultimately led to their return to two museums and a state medical examiner's office. In two of the cases the sellers themselves purportedly came into possession of the remains from estate sales, with the possibility to find out about the original criminal or negligent act being lost. Information on how the skull was procured by the seller or a middleman from one of the museum cases is unknown. Those involved with the trade often represent themselves to prospective buyers or other collectors in diverse ways, from one-time sellers who are seemingly ignorant of the history or value of specimens, or else they appear as "expert" collectors flouting their wares and knowledge as inspiration to others. Given the sometimes shocking nature of items offered for sale, or the proffered story behind their acquisition, or the sparse provenience and ownership history presented to potential buyers, a fundamental understanding of the dynamics of this trade is needed.

\section{Methodology}

The overall goal of the research presented below is to begin to map the human remains trade on Instagram; a first step leading to more in-depth research. In selecting Instagram for this purpose the authors in no way suggest that this particular social media platform engages deliberately or as a matter of routine in any questionable conduct. It is apparent that condiderable attention has been given by the platform to the development of clear, relevant and ethical rules of engagement by Instagram service users. However, not all users conform with these rules and some misuse them for other less honourable purposes. Enforcement of the rules and indentifying at risk behaviour is a major challenge requiring constant vigilance by all in the contemporary "online world" in which we now most typically operate. Instagram is no exception.

We were most interested in beginning to understand the geographic extent of the collecting community, their potential connection to other categories of licit or illicit trade, other online subcultures, as well as the diversity of the categories of human remains obtained or sought. To collect preliminary data on the human remains trade on Instagram, we gathered data primarily via manually searching out and following hashtags such as \#trophyskulls, \#realbone, \#humanbone, etc. The use of hashtags guides users and dedicated researchers towards items and users of interest and allows like-minded individuals and collectors to 
network, collaborate and share their collections with followers. Searches were conducted primarily by two of us (DH and NC) from approximately late 2015 to early 2016 during three distinct search periods. Altogether, data mining comprised at least two months of total investigation, with searches conducted every few days. All images and associated comments and metadata (i.e. number of likes, geolocational information, etc.) were manually captured using screen-shots and stored on Power Point slides according to the 'handle' (user-created identification) of each individual's profile.

During each data mining period, the publically available profiles of each previously noted individual collector, dealer or human remains trade "enthusiast" was re-visited to record updates, changes, or whether the account had become 'private'. Following this reexamination, the search for additional participants continued. From the data obtained, tables were created that present the total number of collectors/dealers active within a given location, or collecting specific categories of human remains, etc. It becomes apparent which locations have the most active supply and demand for each type or category of human remains and what the general demographic structure of the community is.

\section{Results}

Initial insight into the general size and scope of the human remains trading community on Instagram by means of preliminary, manual, data mining is summed up in Tables 1, 2 and 3. These tables show correlations between general dealer location, the demographic profile of the community (table 1) and general categories of human remains collected, whether skeletal element (table 2) or "cultural" category of human remains (table 3). These tables were created using individual dealer counts per category and were calculated during three distinct periods of manual data mining with the goal of highlighting the number and diversity of observed active accounts over time and from which locations dealers originate.

Eight countries from which dealer accounts originate were identified in our data to-date, with a category for unknown location, and an additional category to account for those whose profile pages never reveal their sex/gender (table 1). The category of "multiple indv" is for those profiles run by more than one individual or displaying/selling a brick and mortar store's overall collection. We chose gender as the most useful demographic axis because age was considered non-variant (and often unindicated in text or photo beyond the obvious participation of adults). (insert table 1 here)

Slightly more than half of the profiles identified clearly belonged to individual males, a finding relatively consistent with preliminary results of investigating other facets of the community, as reported in Huffer and Chappell (2014). Of those profiles operated by individuals $(n=62)$, the proportion of males increases to $61 \%$. However, with the exception of the US, our data set suggested a relatively equal participation in the Instagram human remains collecting community by men and women, at least as viewed from their public profile. North America had the bulk of collectors seeking to import new material, but the UK was not far behind and from this initial dataset it seems likely that those profiles in the "unknown" categories would also belong to men. The under-representation of collectors or dealers based in Europe, the Asia-Pacific region, or elsewhere could be due to a variety of factors including expense, perceived legal risks, the stated preference of many US based dealers to only ship within the US, etc. 
In table 2, "whole skeleton" indicates a complete articulated or disarticulated skeleton either assembled on a stand or stored in a box. "Torso" indicates any combination of articulated or disarticulated vertebrae, ribs or pelvis, with or without the skull. "Extremity" refers to articulated or disarticulated hands, feet, legs or arms. "Teeth" refers to both loose teeth (i.e. dental cast-offs) and teeth repurposed for jewellery. "Tissue" here refers to any element that still retains a substantial amount of preserved tissue such as tendon, muscle fibre, skin or hair. "Juvenile" here refers to skulls or whole skeletons from all young subadult age classes from foetus to approximately five years old. (insert table 2 here)

As expected, the majority of specimens displayed or discussed were skulls, accounting for $40 \%$ of the total. The remaining categories are relatively equally represented numerically in our current data, but indicate that specimens such as disarticulated feet or hands can more readily reach collectors. A surprising number of uncleaned or unprepared specimens, including allegedly authentic "shrunken heads" and mummified remains, were encountered. The total number of whole skeletons was also more than expected. Several collectors in the primary "demand" countries also sought juvenile skeletons, usually complete, but sometimes just skulls or mandibles, and pathological specimens were enthusiastically discussed. Only three dealers were noted to be using obvious replicas in their artwork or (in one case) their self-proclaimed Haitian Vodou practice.

In table 3, "anatomical" includes medically dissected actual or alleged teaching specimens, whole or partial articulated skeletons (adult or sub adult), dental off-casts, etc. "Trophy skull" includes real or claimed genuine specimens of "headhunting" from various Southeast Asian, Papuan, Melanesian or South Asian cultures such as the Dayak, Asmat and Naga. This category also included tsantsa ("shrunken heads"). "Archaeological" primarily includes fleshed mummy skulls or body parts, as well as any specimen claimed to be "ancient" or from an archaeological culture (i.e. Paracas "elongated" skulls from Peru). "Historic" is a grey area including specimens that are not medically prepared and, in many cases, show taphonomic [burial environment] damage, but are either claimed to be from historic battlefield contexts (i.e. Civil War), or show pathologies more common to historic populations. Finally, "other" includes miscellaneous isolated elements of unknown age, jewellery made from teeth, etc.

The results indicate the majority of identified items for sale, auction or on display were real or claimed to be anatomical or historic specimens, with those falling into the "trophy skull" or "other" categories being nearly equal. As expected, very few real or alleged ancient archaeological specimens were encountered. Collectors/dealers based in the US once again comprised the majority of the sample, but notable was at least one individual from Denmark, Finland and Indonesia (in this preliminary data set). It is likely that future research on other social media and e-commerce platforms, especially non-English language ones such as Marktplaats in the Netherlands, would reveal an even greater geographic range (insert table 3 here).

\section{Interrelationships and Attitudes within the Human Remains Trade Community}

The attitudes of collectors and sellers are apparent through scrutiny of comments on collector's posts. The reason for posting of comments varies, though typically a degree of awe, covetousness and admiration are expressed. This is especially the case when items deemed especially unique due to their age, condition, or how frequently human remains from 
the culture in question surface on the market. In addition, this ability to follow hashtags and comment on others photos with additional hashtags or personal contact details provides an avenue by which individuals may be directed to items of interest by other known buyers and sellers (insert fig. 1 image here). The item in question is a single adult skull with a woven fiber covering, inlayed with cowrie shells. The adorned skull appears to be suspended from the ceiling by cordage attached to the headdress. The mandible and most teeth are missing, likely post-mortem, as is common for ethnographic human remains from the Asia-Pacific region. The anonymized comments show the amount and nature of communication often affiliated with unusual or unique archaeological or ethnographic human remains. Three commenters express their amazement over the nature and quality of the piece and inquire as to its origins, to which the displayer gives a vague response. One commenter inquires about whether the item is available, to which the current owner suggests it is not. Another commenter adds that they too have many such items available for trade.

Although no price was given, vague mention was made of its ownership history and its moves between international collections, as well as on and off country-specific e-commerce sites before being displayed more widely on Instagram by its current owner. Most human remains observed for sale or trade did not have this level of dialog associated with them, however.

Perceptions of the trade in human remains in the media vary significantly. In an article by Davis (2015), the considerably large and rare collection of one individual was highlighted, with the collector commenting on his personal "human bone museum". Rarely, a collector, or rarer still, a self-identified practicing archaeologist or anthropologist, would question the presence of specific objects for sale, especially with regard to state, national and international law, as seen in the dialog below.

-Commenter 1: I'm an archaeologist and wonder where you get all your skulls?

-Commenter 2: What a nice job! I buy and trade skulls with others, sometimes via the internet.

In a thread from a separate post:

-Commenter 1: Is the keeping of skulls illegal? Any paperwork involved? I am asking out of curiosity.

-Commenter 2: Most places, it is completely legal to own or sell human remains, no paperwork needed. Animal remains are a different story.

-Commenter 1: I thought it was illegal these days? I read that somewhere.

-Commenter 2: Buying Native American remains is illegal. Otherwise it is completely legal depending on your state laws.

Responses to these questions (if they were asked at all) varied, with the seller typically stating their opinion that given specific circumstances, the trade of human remains was both valid and legal, though caveat emptor [Latin for "buyer beware"] was often quoted to the prospective buyers of specific pieces. 
An additional aspect of the human remains trade on Instagram was the prevalence of auctions and give-aways of specimens, perhaps as a means for more prolific collectors to thin out "stock" by discarding small, isolated, skeletal elements, while also attracting more attention and perhaps enticing new collectors otherwise put off by sometimes prohibitive price tags. Skeletal elements ranging from mandibles to femora to carpal phalanges (finger bones) were among items offered, with only very occasional public awareness of this somewhat common phenomenon, at least as seen on Instagram (Augenstein, 2014). One such example encountered stated (paraphrased): "One hell of a give away. A human mandible as a prize + two other winners." A commentator below the image advertising the give-away mentioned how "rad" (incredible or excellent) the offered prize would be in their collections, and another attested to previous dealings with the company in question and identified the city. Numerous examples, typically organised through "sharing" links to the sellers' posts, were encountered, with contact emails and prices given in dollars, pounds, or euros, although many stressed that they only shipped within the US.

As mentioned above, caveat emptor is highlighted, although most sellers were noted to preface their posts to limit participants to the seller's country of origin. It is unclear if the proceeds obtained from any for-profit auction would be used for anything except the purchase of new specimens. A few other recent examples of online auctions of human remains have been encountered. One UK auction house was actively selling allegedly historic period specimens as recently as October 2016. While the auctioneer made ready use of a website and Twitter, no connection to Instagram was observed. Thus, at present, most examples of auctions on Instagram have been run by and for the Instagram community itself.

As with many other categories of the antiquities and art trade, especially as conducted online (e.g. Fay 2011; Brodie 2014), issues of forgery and authenticity also affect the trade in human remains, whether anatomical, ethnographic or archaeological specimens. When considering the weight and role of forgeries, it is important to separate forgeries from replicas. Resin replicas are commonly created and frequently used as teaching models, whether sold to medical schools or university departments of anthropology and only occasionally acquired by private collectors for use in art.

True forgeries can be made from real human remains of indeterminate provenience which are modified through faking of patina, carving or adorning with cultural decorations such as beadwork or decorative carving, as can be seen with the recent glut of inauthentic skulls advertised as originating with Asmat, Dayak and other cultures from the Indo-Pacific region known historically to ceremoniously retain and decorate ancestor or enemy trophy skulls. Anthropologists can often easily differentiate among archaic, historic and recently deceased remains using visual evidence of post-mortem changes to bone in contrast with the age and effect or lack thereof of associated materials.

Additional scientific methods for discerning between Colonial-era specimens and cultural "forgeries" made from real human remains are still being developed (e.g. Hefner et al. 2016; Willey and Leach 2003). Further work in this area will be of utmost assistance to any law enforcement agencies tasked with investigating and prosecuting illicit dealers (see e.g. McNab 2015; ICE 2011), though determinations are best left to trained forensic anthropologists. As far as the collecting community is concerned, the question remains as to the degree of importance collectors place on "cultural" authenticity, and how many 
individuals amassing collections acquire items such as trophy skulls or anatomical specimens that are in fact forgeries.

The human remains trade on Instagram has also been observed by the authors to have correlations with other categories of collecting, both licit and illicit. These range from unlawful trade in wildlife parts like ivory, skins, horns and hooves to the collection of medical implements, ethnographic objects and other categories of "tribal art" not incorporating human remains, WW2 and Civil War memorabilia, and other antiquities. Table 4 quantifies this overlap by displaying the total number of individual collectors whose Instagram profiles indicate their residence in a particular country with tallied indications (from pictures or text) of their participation in or tacit appreciation of other collecting communities. Some categories contain several subcategories of otherwise separately procured or traded items. For example, our category of "war memorabilia" can include WWII, WWI or U.S. Civil War memorabilia. "Wildlife" includes both skeletal and taxidermy specimens.

This latter category was selectively sampled as total numbers of individual examples from all collectors combined for a particular location number in the thousands.

Table 4 presents data indicative of correlations between the Instagram human remains trade community and other collecting communities. Tallies for each row and column are calculated using individual dealer counts. "Medical implements" here refers to antique medical instruments, from bone saws to medicine bottles. "War memorabilia" here refers collectively to all categories of war relics; bullets, weapons, uniforms, medals, flags, from past conflicts, especially World Wars I and II. "Ethnographica" refers to all categories of "tribal art", not including human remains, but including antiquities, whether authentic or likely forgeries. "Wildlife" refers to whole or partial faunal specimens, either skeletonized or taxidermy, domestic or endangered. Finally, "other" includes artefacts outside these categories. Medical implements account for $23 \%$ of the total, with most of the tally coming from a few prolific US based collectors. The simultaneous acquisition of faunal specimens (including such rare species as elephants and orangutans) by human remains collectors regardless of country is somewhat surprising, but these allegedly legally and ethically collected faunal specimens account for $30 \%$. (insert table 4 here). Correlations between the human remains trade and other forms of trafficking are only beginning to be investigated, but these preliminary observations illustrate the potential for meaningful research to examine these overlaps from both a sociological and legal perspective.

A significant finding in the above data, concerning human remains themselves, is the presence of relatively few collectors whose images or posted information identified their location as being France, Belgium, The Netherlands or Germany. Each of these countries is known from previous research (e.g. Huffer and Chappell 2014) to have active collectors, especially of Southeast Asian, Pacific and Africa "trophy skulls", as well as to be a source of allegedly historic or Medieval European crania or complete skeletons. As also seen in table 3 above, only individual with profiles suggesting residence in Belgium are present. This includes both those whose profiles suggested they only collected as well as those who claimed they collected, auctioned and sold. It is possible that collectors from these countries had for the most part moved from Instagram to other social media platforms, such as Facebook groups. Indeed, one such group devoted to palaeopathology (the study of health and disease in past populations using skeletal remains) routinely attracted a small number of collectors from The Netherlands who requested assistance from the bioarchaeological 
community to identify osseous manifestations of pathology. It is likely that future researchers, over a much longer time frame and using automated search methods that can improve the speed and scope of social media data mining (e.g. Huffer and Graham 2017, 2018) will more accurately reveal the contributions of collectors from these countries to the global online trade.

The data offered here is meant to be a preliminary analysis of this evolving face of the human remains trade. It is anticipated that, as automated methods of data mining as well as other social media platforms are investigated, more comprehensive data will be uncovered. Bringing such techniques to bear will prove important for searching through the comment "noise" to look for patterns in the type and nature of comments associated with each image and the connections between users, as evidenced by the linked appearance of their usernames or by cross-referencing content. This is the subject of ongoing research (Huffer and Graham 2017 , 2018). Importantly, the periods of data recording included here occurred before and after an interview of one of the authors (DH) for Forbes magazine (Killgrove 2016b). The dissemination of this interview appears to have "shaken up" the Instagram human remains trading community resulting in a change in online trading practices and more guarded behaviour. Although the Instagram community may have become more cautious and has, to some extent, moved to other platforms, the data already obtained is telling and presents a novel avenue to understand better both the human remains trade and other aspects of the antiquities market more generally.

\section{Legal Issues and Current Loopholes}

We have referred earlier to some of the uncertainties and vagaries encountered in the legal environment regarding the trade in human remains. It is not our intent here to provide a comprehensive appraisal of this environment worldwide which is a task already performed to a large degree by Marques-Grant and Fibiger (2011) in their seminal international study of the laws and practice applying to the excavation and treatment of archaeological human remains. However, as the locus of much of the trade revealed in our present study is situated in the US or UK we feel it is important to say more about some of the legal complexities involved and describe how the law applies in practice in those jurisdictions. We also refer in brief to comparative laws in several other jurisdictions in Europe and elsewhere.

In the US, legislation on the human remains trade at the Federal and State level does not necessarily work in concert, and confusion remains as to what laws apply in various circumstances (see in general Ubelaker 2011). Federal legislation regulating or prohibiting the procurement and collection of human remains is to be found in a number of sources including the Native American Graves Protection and Repatriation Act 1990 (NAGPRA); the Uniform Anatomical Gift Act of 1968 (UAGA), as amended in 1987 and 2006; and a range of regulatory measures administered by the US Food and Drug Administration (FDA) concerned with the acquisition of human tissue for transplant and allied medical procedures. State-specific legislation also applies in Louisiana, Georgia, Missouri and Tennessee, as is sometimes acknowledged by various collectors.

The UAGA is a crucial piece of legislation regarding the legality of owning, displaying, or selling human remains for private and commercial purposes in the US. A Uniform Act is a proposed state law drafted by the Uniform Law Commission and approved by its sponsor, the National Conference of Commissioners on Uniform State Laws (NCCUSL) (Uniform Law 
Commission n.d.). The original UAGA was drafted in 1968 and since then has been amended a number of times. The UAGA has also been enacted in every US state since 1968, yet, there is still a lack of uniformity and harmonisation in the actual version of the UAGA, adopted at different times by individual jurisdictions. For instance, Section 16 of the current (2006, revised in 2009) UAGA prohibits the buying and selling of human body parts, primarily organs, under certain circumstances. Under this section, buying and selling skeletal human remains is generally legal, but not every state or territory adheres to the same version of this legislation. For example, in Massachusetts, Section 16 states:

"Section 16. (a) Except as otherwise provided in subsection (b), a person who for valuable consideration, knowingly purchases or sells a part for transplantation or therapy if removal of such part from an individual is intended to occur after the individual's death shall be punished by imprisonment in the state prison for not more than 5 years or in the house of correction for not more than 21/2 years, or by a fine of not more than $\$ 50,000$ or by both such fine and imprisonment."

Other States and territories in the US interpret this section, and the UAGA itself, as a total ban on the purchase or sale of human body parts within their jurisdiction for both medical purposes and personal collection. In the United States, the American Association of Tissue Banks (AATB), has developed standards, policies and an accreditation process for NonTransplant Anatomical Donation Organizations (NADOs) in response to numerous scandals involving unregulated trade in body parts for medical education (Waltz 2007). NADOs are non-profit and for profit companies that supply human remains for scientific research and medical training. New York is currently the only state in the US to require a state-issued license for any NADOs doing business within the state including outside NADOs sending remains into New York.

In the United Kingdom, human remains can be kept privately, but remains less than 100 years old must not be used for display without a Human Tissue Act 2004 (HTA) licence. There is a complication in that. Under current UK legislation one cannot "own" human remains, but can have custody of them. Guidelines from the Department of Culture, Media \& Sport (DCMS) note in more details that:

"Museums and other institutions holding human remains should ensure that any activities that they undertake in relation to human remains are lawful. The law in relation to human tissue has recently changed following the Human Tissue Act 2004, the primary purpose of which is to regulate the removal, storage and use of human tissue for listed activities, which include research and public display. The Human Tissue Act requires that regulated activities are undertaken only with the prior consent of the individual from whom the tissue is taken. Significantly, existing holdings, imported remains and human remains that are older than 100 years fall within exemptions to the requirement for consent. In practical terms, this means that the activities of museums and other institutions with collections of older human remains will fall largely outside the consent regime of the Act because of the age or origin of the majority of the remains in their collections. The Human Tissue Act also creates a Human Tissue Authority which is to administer a licensing regime and to issue codes of practice. Where museums and other collections hold the remains of individuals who died less than 100 years ago, they may in due course be required to hold a licence to continue to store and use 
such material, and to comply with codes of practice issued by the Human Tissue Authority as a condition of such licence (DCMS Guidelines 2005: 11)"

The more recently published Human Tissue Authority's [HTAuthority] various Codes of Practice (2017) further caution importers of human remains into the United Kingdom of the need

"to satisfy themselves, with due assurance from their collaborators abroad, that any material intended for import is sourced consistently with the legal and ethical review requirements in England, Wales and Northern Ireland. When an individual, establishment or organisation imports material into England, Wales and Northern Ireland for research, it is good practice for approval to be obtained from a research ethics authority or the local equivalent in the source country beforehand." (HT Authority 2017 Research Code of Practice: 27)

Furthermore, the legislative requirements of the HTA do not apply to skeletal remains that are over 100 years old. The HTAuthority's 2017 Public Display Code of Practice states that:

"Where the age of the material is unknown, as no documentary evidence such as archival records, receipts or scientific evidence (e.g. carbon dating) is available [a curatorial age must be attempted]. Where investigations are inconclusive and it is uncertain whether the material is over 100 years old or not, the earliest known acquisition date may be taken as an indicator of the age of the material. Where no acquisition date is available, an HTA licence should normally be applied for." (HTAuthority 2017 Public Display Code of Practice : 14)

It is possible to obtain expert advice, such as from a biological anthropologist at a "wellrespected academic institution" and get a statement from them saying that in their professional opinion the remains are more than 100 years old and hence no HTAuthority licence is required.

The HTAuthority has a core principle that all human bodies and relevant material within its overall scope should be treated with respect and dignity. It actively links its own requirements and advice with that given for the curation, care and use of human remains by the DCMS. Indeed, even the storage of human remains is covered by the DCMS guidelines, with a requirement that storage needs to be actively managed and monitored and needs to meet certain security standards. The display of human remains is of prime interest, with the guidelines stating that human remains should not be displayed unless the actual skeletal material makes a real and "material contribution to a particular interpretation; and that contribution could not be made equally effectively in another way" (DCMS guidelines: 20). So, human remains may be kept, but not owned, and should not be displayed unless absolutely necessary to aid in understanding and interpretation. Many European countries, including those mentioned in the tables above, are signatories to the 1970 UNESCO Convention and have legislation in place governing how museums and archaeological excavations handle and repatriate human remains (Marquez-Grant and Fibiger 2011), but specific legislation prohibiting ownership, transport or purchase (outside the realm of funeral homes) is not readily available. 
In Australia, certain states have their own human tissue act (e.g. New South Wales: HTA 1983) that has proven to be enforceable in halting sales of archaeological or ethnographic human remains at auction (Morgan 2010). New Zealand also has its own legislation (HTA 2008) that prohibits collection or importation of any human tissue without consent.

Fundamentally, however, internationally cohesive legislation using the same terminology and forbidding or permitting the same activities within the private, commercial, human remains trade, does not yet exist, and might never, given differences in how cultural heritage and cultural property are defined, differences in what constitutes ownership, and many other discrepancies.

\section{Interpretations and Further Research Directions:}

The preliminary data discussed above is merely the first step in ongoing efforts to understand and map the online human remains trade on Instagram and other social media platforms. While we have presented pilot level qualitative and quantitative results from two distinct periods combined from investigating the Instagram human remains trading community, there are other aspects of the contemporary trade noted in passing here that deserve more intensive research in future.

Chief among these topics is the looting and selling of real or alleged "war dead", primarily (in the examples seen to date) claimed to be Civil War soldiers exhumed from Southern battlefields. One such example has a caption that reads (paraphrased): This is a southern Civil War soldier found in a clay bed, still with clay on it. Own a piece of history. Serious inquires only please. This back story is intended to attract only the most dedicated collector, and what appears to be soil still attached. Interested parties can own a piece of history but only "serious inquiries" are welcome. In this example and others like it, the alleged origins and rarity of the skull in question is a key selling point. Confirming the specific stated origins of such specimens is highly unlikely. Any investigations require a concerted effort to determine the extent of ongoing or recent battlefield looting events, and isotopic geochemical research to more accurately determine 'provenience' in forensic contexts (e.g. Fraser, Meier-Augenstein and Kalin 2006; Meier-Augenstein 2010). Such measures will ensure physical anthropologists and isotope geochemists will increasingly aid investigations and their research can help investigate cases of smuggled cultural property containing human remains.

One might ask what has fuelled this specific aspect of the human remains trade? Television shows such as "Nazi War Diggers" (since renamed "Battlefield Recovery" and re-aired on British TV's Channel 5) have attempted to display the "excitement" of finding and, allegedly, preserving WWII sites along the Eastern Front. Episodes depicted the looting of battlefields and graves, including the on-air haphazard excavation of human remains. When initially aired, this show, and two others like it, met with concerted outcry from the global archaeological community (Winston 2016; Mashberg 2014; The Local 2016). The rebirth of Nazi War Diggers stands as a reminder that outcry by cultural heritage experts is not enough to affect collector attitudes or prevent from the public encouragement of new trade (e.g. Thomas 2015).

The looting and selling of human remains and associated artefacts from battlefield cemeteries are not confined to Europe. One of the more well-documented cases occurred at Ft. Craig, New Mexico, where 67 burials were excavated by Bureau of Land Management (BLM) archaeologists only after being tipped off that extensive looting had been occurring since at 
least the 1970s (Associated Press 2008). Other more recent instances of Civil War battlefield looting have also occurred where selling of the remains was not the primary purpose (Preuss and Gast 2016; Burnes 2012). From some collectors, the collection of war dead coincides with collection of other material expressions of "dark heritage" (e.g. Herva et al. 2016) or their participation in "dark" tourism (e.g. Biran, Poria and Oren, 2011). To date, published examples of the buying and selling of Civil or World War-era human remains are very rare, even in the popular press. Therefore, gauging the full extent of this face of the human remains trade is a fruitful avenue for future work.

The trade in human remains online has not gone entirely unnoticed by the public. In addition to the recent ban by eBay, primarily in response to Halling and Seidemann (2016) (see Vergano 2016 for discussion), a few other instances of attempted "creative" sales or auctions by other platforms have been exposed (e.g. Killgrove 2016a). At the individual level, a few proprietors of "the macabre" present clear ethical statements against participation in the trade. For example, a Halloween prop store based in Los Angeles, CA, presented the following paraphrased statement on their website circa 2015.

“...You might think it odd, but I get asked for human remains a couple times a day, and every couple of months someone asks if I'm interested in buying some human remains that they have, for some reason... The laws on who can legally buy and sell human remains are fairly complex, so the rule of thumb to go by is this - buying, selling, or owning human remains is illegal... The sources of human remains are, at some point, living humans... The rest of the bones that are being sold are archaeological theft, contemporary grave robbing, war trophies, criminal evidence, and a mixed bag of specimens passed from hand to hand for so long the origins, legitimate or not, are long since lost. The burden of proof is on the owner... I urge anyone who's interested in buying bones to buy replicas. It's the only ethical choice. Otherwise you are supporting or encouraging a black market in endangered species, fossil and archaeological treasures, and human life."

As detailed above, it is rare to see collectors or dealers taking anything more than a 'caveat emptor' stance with regard to legal or ethical concerns. However, some individuals are beginning to take stances against wanton criminal activity, even if caveats are still offered so as to reassure any new customers with more concern for ethics than is usual. For example, a dealer with a brick-and-mortar store and online gallery out of the UK (Pandora's Box n.d.a) states on their website:

"Ethics: We believe this to be defined as a generally accepted standard of right and wrong. It may have different meanings to different individuals; however, it is actually about a generally accepted standard of what is morally right. You may think we are 'unethical' by your own personal standards but we are not without standards or a moral code that determines what we will and won't do. Please respect our ethical standards and position yourself in a place of assuming we would always do the right thing rather than the wrong thing. We never harm any animals for our work. Ever."

In regard to their "ethical" interpretation of the current HTAuthority legislation in the UK (and its US equivalent) they (Pandora's Box n.d.b) state: 


\begin{abstract}
“'Sale of Body parts for other uses.' This means skulls and bones for use when housed in a private collection. Not for public display, not as props or to be sold as Halloween decorations. These skulls are not allowed to be displayed to the public without license, and must be treated with respect and dignity.
\end{abstract}

We sell human bones and skulls for the purpose of completing an individual's private collection. Cabinets of curiosities have contained human skulls and bones for as long as they have been in existence and that is the type of item we supply. We do not sell skulls and bones for any other reason than this. We handle remains with the utmost respect and we do not ever forget that they were once a living and breathing human being.

U.S. Answer: We notice that the U.S. laws seem to be evolving in regards to human bones and remains and as such we cannot offer these items to U.S. customers or refer you to a seller in the U.S. as we would not want to break or even stretch the law. As of July 2016 our Pandora's Boxes to the US will not contain any human parts or bones including as components of jewellery or in the form of antique medical slides or pathological samples at all, without exception.”

With more study and exposure, public awareness of the existence of the commercial trade itself will continue to grow. The combination of long-term qualitative and quantitative databases that illuminate the nature of the human remains trade, as well as its connection to other questionable trading communities will only increase the potential for successful prosecutions and repatriations. Ideally, new research will also increase public pressure to demand more comprehensive and uniform legislation at the national and international levels.

\title{
Conclusion
}

Overall, this chapter suggests that a complex international market for human remains exists on social media platforms like Instagram over a variety of categories readily available for appreciation, auction, sale or trade. While future work will continue to track the market on this platform, the manual approach to data mining taken here can also be applied to searching other active social media platforms that are used to arrange sales. These include Etsy (where the sale of human remains has allegedly been banned (Kim 2012). However, jewellery containing human teeth, allegedly from ethically sourced dental offices, remains available. Also worthy of much more investigation is Facebook, especially given the large number of "closed" or "secret" groups through which illicit trade of all types can occur (e.g. Lapowsky 2018). Since 2012, Facebook has owned Instagram and thus the movement of the personal profiles and merchandise of prolific sellers between the two platforms is more feasible than ever. Less frequently used platforms, such as Tumblr or Pinterest, can also be used as virtual "display boards" for collectors and dealers to surreptitiously advertise what they have, while Twitter makes is very easy for collectors to link with dealers under the same or different handles used on Instagram, as well as send direct messages to each other.

The next steps in understanding the demand side of the trade as facilitated by Instagram and other social media platforms, will be to examine the functioning of the networks themselves and look in more depth at the rhetoric and "grammar" of how human remains are bought, sold, and marketed, how the community helps or hinders those suspected of too egregiously breaking the law, and how the trade continues to evolve. The results of manual searching 
discussed above undoubtedly only serve to represent the tip of the iceberg. This work is laying the foundation for planned research over the next several years. Future research will explore the utility of machine learning/neural network analysis to better extract patterns in the ebb and flow of online trade in human remains.

\section{Disclaimer:}

The opinions and assertions contained herein are those of the author(s) and do not necessarily represent the views of the National Museum of Health and Medicine, the U.S. Department of Defense (DoD) or any other U.S. government agencies and does not constitute an endorsement by the DoD of any of the opinions expressed, or any information contained therein.

\section{Bibliography:}

Anatomical Gifts Act (2006). Anatomical Gift Act (2006). [online] Uniform Law Commission. Available at: http://www.uniformlaws.org/Act.aspx?title=Anatomical\%20Gift\%20Act\%20(2006) [Accessed 01 Mar.2017].

Associated Press, (2008). Thieves steal remains from Civil War-era graves. [online] NBC News. Available at: http://www.nbcnews.com/id/24022697/ns/us_news-military/t/thievessteal-remains-civil-war-era-graves/ [Accessed 20 Dec.2016].

Augenstein, S. (2014). Macabre auction includes vampire-slaying kit, human skull, demon mask. [online] NJ.com True Jersey. Available at:

http://www.nj.com/bergen/index.ssf/2014/10/auction_of_the_macabre_bergen_county_estate _auction_includes_human_bones_and_vampire-slaying_kits.html [Accessed 22 Dec.2016].

Banerjie, I. (2014). Skeleton exports: Bizarre trade [online]. India Today. Available at: http://indiatoday.intoday.in/story/government-bans-export-of-humanskeletons/1/354694.html [Accessed 14 Mar. 2017].

Biran, A, Poria, Y, Oren, G. (2011). Sought experiences at (dark) heritage sites. Annals of Tourism Research 38(3), pp.820-841.

Bright, D.A., Hughes, C.E.,Chalmers, J. (2011). Illuminating dark networks: a social network analysis of an Australian drug trafficking syndicate. Crime, Law and Social Change 57(2), pp.151-76.

Brodie, N. (2014). The internet market in Pre-Columbian antiquities. In: J. Kila and M. Balcells,eds., Cultural Property Crime: An Overview and Analysis of Contemporary Perspectives and Trends, $1^{\text {st }}$ ed. Leiden: Brill Press, pp. 237-263.

Burnes, B. (2012). Springfield man admits taking bones from Civil War battlefield. [online] The Kansas City Star. Available at: http://www.kansascity.com/news/local/article310819/Springfield-man-admits-taking-bonesfrom-Civil-War-battlefield.html [Accessed 21 Dec.2016].

Carter, C., Vilches, F., Santoro, C.M. (2016). South American mummy trafficking: Captain Duniam's nineteenth-century worldwide enterprises. Journal of the History of Collections, doi: 10.1093/jhc/fhw031. 
Choi, CQ. (2011). NY mummy smugglers reveal vast antiquities black market. [online] Live Science. Available at: http://www.livescience.com/15234-ny-mummy-smugglers-revealvast-antiquities-black-market.html [Accessed 12 Aug.2015].

Contreras, D.A.(2010). Huaqueros and remote sensing imagery: assessing looting damage in the Virú Valley, Peru. Antiquity 84(324), pp.544-555.

Contreras, D.A. and Brodie, N. (2010). The utility of publicly-available satellite imagery for investigating looting of archaeological sites in Jordan. Journal of Field Archaeology 35(1), pp. 101-114.

Davis, S. (2015). Meet the living people who collect dead human remains. [online] Vice.

Available at: http://www.vice.com/read/meet-the-living-people-who-collect-human-remains713 [Accessed 04 April2016].

Fetcher, J. (2016). Instagram photos claim ties to 'El Chapo,' show off Mexican drug cartel exploits [online] San Antonio Express News. Available at:

http://www.mysanantonio.com/news/us-world/article/Mexico-cartels-El-Chapo-Instagramguns-money-6493872.php\#photo-8640615 [Accessed 30 Mar.2016].

Fay, E. (2011). Virtual artifacts: eBay, antiquities, and authenticity. Journal of Contemporary Criminal Justice 27(4), pp. 449-464.

Fraser, I., Meier-Augenstein, W., Kalin, R.M. (2006). The role of stable isotopes in human identification: a longitudinal study into the variability of isotopic signals in human hair and nails. Rapid Communications in Mass Spectrometry 20(7), pp. 1109-1116.

Gill, J.R., Rainwater, C.W., Adams, B.J. (2009). Santeria and Palo Mayombe: skulls, mercury and artifacts. Journal of Forensic Sciences 54(6), pp.1458-1462.

Goel, V and Isaac, M. (2016). New Facebook policy bans talk of private gun sales, applies to Instagram [online]The New York Times. Available at:

http://www.nytimes.com/2016/01/30/technology/facebook-gun-sales-ban.html?_r=0 [Accessed 29 Mar. 2016].

Halling, CL and Seidemann, RM. (2016). They Sell Skulls Online?! A Review of Internet Sales of Human Skulls on eBay and the Laws in Place to Restrict Sales. Journal of Forensic Sciences 61(5), pp. 1322-1326.

Haslett, C. (2015). Click to like this: Is Instagram a hub for illegal ape deals? [online] Mongabay. Available at: http://news.mongabay.com/2015/12/click-to-like-this-is-instagrama-hub-for-illegal-ape-deals/ [Accessed 24 Mar.2016].

Hefner, J., Spatola, B.F., Passalacqua, N.V., Gocha, T.P. (2016). Beyond taphonomy: Exploring craniometric variation among anatomical material. Journal of Forensic Sciences 61(6), pp. 1440-1449.

Herva, V.-P., Koskinen-Koivisto, E., Seitsonen, O., Thomas, S. (2016). 'I have better stuff at home': treasure hunting and private collecting of World War II artefacts in Finnish Lapland. World Archaeology 42(2),pp. 267-281. 
Huffer, D. and Chappell, D. (2014). The mainly nameless and faceless dead: an exploratory study of the illicit traffic in archaeological and ethnographic human remains. Crime, Law, and Social Change 62(2), pp.131-153.

Huffer, D. and Graham, S. (2017). The InstaDead: The rhetoric of the human remains trade on Instagram. Internet Archaeology 45, doi: 10.11141/ia.45.5.

Huffer, D. and Graham, S. (2018). Fleshing out the bones: Studying the human remains trade with Tensorflow and Inception. Journal of Computer Applications in Archaeology 1(1), pp. 55-63.

HTA (1983). Human Tissue Act 1983. [online] New South Wales Consolidated Acts. Available at: http://www.austlii.edu.au/au/legis/nsw/consol_act/hta1983160/ [Accessed 16 Feb.2017].

HTA (2004). Human Tissue Act 2004 [online] Legislation.gov.uk. Available at:http://www.legislation.gov.uk/ukpga/2004/30/contents [Accessed 1 Mar. 2017].

HTA (2008). Human Tissue Act 2008 [online] New Zealand Legislation. Available at: http://www.legislation.govt.nz/act/public/2008/0028/latest/whole.html [Accessed 16 Feb.2017].

Huxley, A.K. and Finnegan, M. (2004). Human remains sold to the highest bidder! A snapshot of the buying and selling of human skeletal remains on eBay®, an internet auction site. Journal of Forensic Science 49(1), pp. 1-4.

ICE (2011). ICE returns tribal artifacts to Indonesian authorities [online] ICE Newsroom. Available at: https://www.ice.gov/news/releases/ice-returns-tribal-artifacts-indonesianauthorities [Accessed 11 Mar. 2017].

Joffe, A. (2016). ISIS and antiquities: The missing pieces [online] The National Interest. Available at: http://www.nationalinterest.org/feature/isis-antiquities-the-missing-pieces15005 [Accessed 25 Mar.2016].

Killgrove, K. (2016a). Mummy crowdfunder leaves archaeologists fuming [online] Forbes. Available at: http://www.forbes.com/sites/kristinakillgrove/2016/10/10/mummycrowdfunder-leaves-archaeologists-fuming/\#115d303f1d2d [Accessed 12 Aug.2016].

Killgrove, K. (2016b). This archaeologist uses Instagram to track the human skeleton trade [online] Forbes. Available at: http://www.forbes.com/sites/kristinakillgrove/2016/07/06/thisarchaeologist-uses-instagram-to-track-the-human-skeleton-trade/\#21f3602430b1, [Accessed 08 June2016].

Kim, E. (2012). Etsy blocks sales of drugs and human remains [online] CNN Tech. Available at: http://money.cnn.com/2012/08/10/technology/etsy-bans-drugs/ [Accessed 20 Dec.2016].

Kinkopf, K.M. and Beck, J. (2016). Bioarchaeological approaches to looting: A case study from Sudan. Journal of Archaeological Science: Reports 10(1), pp. 263-271.

Kubiczek, P.A. and Mellen, P.F. (2004). Commentary on: Huxley AK, Finnegan M.; Human remains sold to the highest bidder! A snapshot of the buying and selling of human skeletal remains on eBay, and internet auction site. Journal of Forensic Science 49(5), pp.17-20. 
Lapowsky, I. 2018. How Facebook groups became a bizarre bazaar for elephant tusks [online] Wired.com. Available at: https://www.wired.com/story/tusks-horns-and-clawsinside-the-fight-to-destroy-the-animal-parts-bazaar-on-facebook/ [Accessed 2

Nov.2018].Lasaponara, R., Leucci, G., Masini, N., Persico, R. (2014). Investigating

Formatted: English (U.S.) archaeological looting using satellite images and GEORADAR: the experience in Lambayeque in North Peru. Journal of Archaeological Science 42(3), pp. 216-230.

Lillie, M. (2013). Gang involvement with human trafficking [online] Human Trafficking Search. Available at: http://humantraffickingsearch.net/wp1/gang-involvement-with-humantrafficking/ [Accessed 4 Feb.2016].

McNab, H. (2015). Macabre collection of human skulls taken from an Indonesian tribe and bound for Australia intercepted by customs [online] Daily Mail Australia. Available at: http://www.dailymail.co.uk/news/article-3128950/Macabre-collection-human-skulls-takenIndonesian-tribe-bound-Australia-intercepted-customs.html [Accessed 11 Mar.2017].

Mangione, K. (2016). Human trafficking charges laid after victim contacted over Instagram: police [online] CTV News. Available at: http://toronto.ctvnews.ca/human-traffickingcharges-laid-after-victim-contacted-over-instagram-police-1.2618784 [Accessed 04 Feb.2016].

Marquez-Grant, N. and Fibiger, L. (2011). The Routledge Handbook of Archaeological Human Remains and Legislations. London: Routledge Press.

Mashberg, T. (2014). TV series is criticized in handling of deceased. [online] The New York Times. Available at: https://www.nytimes.com/2014/03/29/arts/television/tv-series-iscriticized-in-handling-of-deceased.html [Accessed 20 Dec.2016].

Meier-Augenstein, W. (2010). Provenancing people. In: W. Meier-Augensteined., Stable Isotope Forensics: An Introduction to the Forensic Application of Stable Isotope Analysis, $1^{\text {st }}$ ed.. London: Wiley-Blackwell Publishing House, pp. 190-213.

Morgan, J. (2010). Expert has a bone to pick with auction house as skull sale called off [online] The Sydney Morning Herald. Available at: http://www.smh.com.au/nsw/expert-hasa-bone-to-pick-with-auction-house-as-skull-sale-called-off-20100804-11foc.html [Accessed 16 Feb.2017].

O'Reilly, D. (2007). Shifting trends of heritage destruction in Cambodia: from temples to tombs. Historic Environment 20(2), pp. 12-16.

Pandora's Box (n.d.a). Ethics and processes. Pandora's Box. Available at: http://www.pandorasboxyork.com/ethics/ [Accessed 21 Jan.2019].

Pandora's Box (n.d.b). Frequently asked questions. Pandora's Box. Available at: http://www.pandorasboxyork.com/faq/ [Accessed 21 Jan.2019].

Preuss, A. and Gast, P. (2016). Civil War battlefield looted, described as 'crime scene.' [online] CNN Regions. Available at: http://edition.cnn.com/2016/05/28/us/petersburgbattlefield-looting/ [Accessed 13 Mar.2017].

Popular Archaeology (2012). Massive looting and destruction at ancient Egyptian archaeological site [online] Popular Archaeology. Available at: http://popular- 
archaeology.com/issue/june-2012/article/massive-looting-and-destruction-at-ancientegyptian-archaeological-site [Accessed 12 Aug. 2016].

Roque, R. 2010. Headhunting and Colonialism: Anthropology and the Circulation of Human Skulls in the Portuguese Empire, 1870-1930. London: Palgrave Macmillan.

Ruiz, C. (2016). What do we really know about Islamic State's role in illicit antiquities trade? [online]The Art Newspaper. Available at: http://theartnewspaper.com/news/what-dowe-really-know-about-islamic-state-s-role-in-illicit-antiquities-trade/ [Accessed 22 Mar. 2016].

Seidemann, R.M. (2004). Bones of contention: A comparative examination of law governing human remains from archaeological contexts in formerly colonial countries. Louisiana Law Review 545, pp. 546-576.

Seidemann, R.M., Stojanowski, C.M., Rich, F.J. (2009). The identification of a human skull recovered from an eBay sale. Journal of Forensic Sciences 54(6), pp. 1247-1253.

Smith IV, J. (2014). Here's every statistic you could want on Instagram drug dealers [online] Observer. Available at: http://observer.com/2014/05/heres-every-statistic-you-could-want-oninstagram-drug-dealers/ [Accessed 29 Mar.2016].

Spennemann, D.H. 2006. Skulls and curios, crania as science: Some notes on the collection of skeletal material during the German Colonial period. Micronesian Journal of the Humanities and Social Sciences 5: 70-78.

The Local, (2016). German war graves are being desecrated on TV [online] The Local.de.. Avaialble at: http://www.thelocal.de/20160113/german-war-graves-being-desecrated-onbritish-tv [Accessed 20 Dec.2016].

Thomas, J. (2016). The strange relationship between Mexican drug cartels and Instagram [online] Big Think. Available at: http://bigthink.com/connected/drug-cartels-social-media [Accessed 30 Mar. 2016].

Thomas, S. (2015). Collaborate, condemn, or ignore? Responding to non-archaeological approaches to archaeological heritage. European Journal of Archaeology 18(2), pp. 312-335.

Ubelaker, D.H. (2011). United States of America. In: N. Márquez-Grant and L. Fibiger, eds., The Routledge Handbook of Archaeological Human Remains Legislation. London:

Routledge, pp. 533-540.

Uniform Law Commission (n.d.) Acts [online] Uniform Law Commission. Available at: http://www.uniformlaws.org/Acts.aspx [Accessed 01 Mar.2017].

Vergano, D. (2016). eBay just nixxed its human skull market [online] Buzzfeed. Available at: https://www.buzzfeed.com/danvergano/skull-sales?utm term=.crgMp03QZ\#.xv3ozNyLq [Accessed 21 Dec.2016].

Waltz, E. (2007). Tracking down tissues. Nature Biotechnology 25(11), pp. 1204-1206.

Willey, P. and Leach, P. (2003). The skull on the lawn: Trophies, taphonomy and forensic anthropology. In: D.W. Steadman, ed., Hard Evidence: Case Studies in Forensic Anthropology. Ann Arbor: Prentice Hall, pp. 176-188. 
Winston, G. (2016). "Nazi War Diggers" renamed "Battlefield Recovery" - Britain's Channel 5 TV accused of disrespecting WWII dead [online]. War History Online: The Place for Military History News and Views. Available atL: https://www.warhistoryonline.com/wararticles/nazi-war-diggers-renamed-battlefield-recovery-britains-channel-5-tv-accuseddisrespecting-wwii-dead.html [Accessed 20 Dec. 2016]. 